\title{
A DEFINITE AIM IN COMPOSITION
}

\author{
GENEVIEVE APGAR \\ Teachers' College, St. Louis, Mo.
}

Much time is often lost in composition work because of a lack of definiteness of aim; much good material is wasted, many rich possibilities are neglected, because a specific end has not been pointed out toward which effort should be directed. The boy who chews the end of the penholder and gazes aimlessly out of the window, when he should be producing a theme full of interest for the class and the teacher, will never get to work till he himself is interested in the subject of his no longer neglected discourse. His own interest will be much nearer the awakening point if the task assigned to him is so definite that it directs his thought along a certain fixed path leading to a natural, but sure, outcome, of sufficient importance to make it worth his while to reach it. In these days, when so much is made of interest as a motive power in education, teachers are prone to overlook the fact that interest does not always come first; that it often follows the conscientious performance of any set task. Many a pupil, lacking interest in a study, will acquire interest if he faithfully attacks the work assigned. He oftentimes will come from that work with more than the mere consciousness of duty performed; he will find that he has discovered that the thing itself holds real interest for him-interest which he had not before dreamed of because of his lack of knowledge of the subject itself.

In composition work, then, interest may be stimulated, and desirable results may be obtained, by directing the pupil to a definite line of thought and giving him a definite purpose for following that thought. With secondary-school pupils more can be accomplished in this way through the frequent writing of short papers, carefully assigned, than through the infrequent production of long papers, even though the assignment of these has made clear their object. The papers which follow are submitted, not as perfect illustrations, but as actual work of high-school pupils; the papers are full of faults, but they possess life and interest. 
A class was asked to write a description of an actual object, being directed to choose such an object as had a number of details, and then to write of it, introducing all the details in as interesting a manner as possible. Some of the subjects taken were "My Study Chair," "My Study Desk," "Our Sewing Basket," "Our Front Lawn." One paper that shows the possibilities in such a subject-possibilities of detailed observation and successful expression-follows:

\section{THE STEAM RADIATOR}

As it is necessary to have iron radiators in a house which is to be heated by steam, they might better adorn the room in which they are fixtures, than disfigure it. Therefore, the radiator which is now giving out its genial heat in rays which come toward me, is all gilded over and ornamented in various ways. Numerous little scrolls circle round and round, finally terminating in a leaf-like design that gradually tapers down either side of one-third of the length of each pipe. Twenty-five of these pipes join each other by little communicating knobs. On both sides at the rounding top of each pipe are more knobs, which have little caves in either side and remind one of ears he has seen. Down at the bottom of the pipes more leaves and scrolls complete the symmetry of the decorative design, but it is not necessary for them to extend as far as the others because the average student passing by, intent on his next recitation, does not notice them. At one end is attached a little tank-shaped affair, which persists in singing a disagreeable tune whenever one is deep in meditative thought and doesn't wish to be disturbed: At the other end is the unadorned, but useful appliance which turns the steam on and off.

So the radiator looks bright and cheerful while performing its duty, and sends out its kindly rays to all.

The next paper, written by a girl of fourteen, upon the same assignment as the preceding one, has a more reflective tone:

\section{A CERTAIN TREE}

Across the road from Bryant's Nurseries stands a large cottonwood tree, whose far-reaching branches, with the aid of the maples on the other side of the road, form a graceful arch over the public highway.

This work of nature has become a landmark, having been almost full-grown fifty years ago. In its hospitable branches birds have built their nests, reared their young, and departed; squirrels have occupied its trunk, raised their families, and passed away; but the tree remains, an emblem of fortitude and endurance. The oak may claim sovereignty for strength, and the pine for sturdiness; but for longevity, which of our trees can exceed the cottonwood?

Many a weary traveler has doubtless rested in the shade of this particular 
one, fanned by the swaying branches and cooled by the refreshing breeze. On warm summer days, when the dancing leaves make fantastic shadows on the dusty road beneath, large flocks of blackbirds hold their councils of war on its upper limbs. The impudent blue jay, the chattering sparrow, and the industrious woodpecker all claim it for their home, while the owl holds his nightly serenade in its projecting shelter.

The old tree seems to stretch out its arms to all the forest creatures, saying: "Come, for here you will find a home, a shelter from the storm, and a haven from all that would harm you." Who would say that the cottonwood has not done its part to further God's great plan in life?

This assignment was followed by a direction to write a description involving some central idea; that is, a description of a person was to be written in such a way as to make prominent some central trait of the person's appearance or character. The titles of some of the papers submitted were "Herbert," "My Elderly Friend," and "Sarah Alice." The descriptions showed "Herbert" to be a quiet, reflective boy; "My Elderly Friend," to be a man who, although of advanced years, was an active, successful business man; "Sarah Alice," to be a girl of careless, heedless ways.

Next the assignment was varied by requiring the description to involve not only a central idea, but action suited to that idea. The following paper illustrates the result:

\section{A "BIT-OF-A-LASS"}

In the morning you may see her as she trudges along to school, her face shining with happiness and the recent application of a washcloth. Talking, talking, talking, she makes one think of a noisy magpie on a bright spring morning. One may learn all her family history, and be asked numerous questions concerning one's own, in about seven minutes. She has one of those "I-am-agood-scholar" faces that one sees so often in school children, and little bright eyes that are ever dancing with glee. Two tiny copper-colored braids hang a little way below her neck and are tied with red ribbons which mingle merrily with the bobbing tassels of her four-cornered cap. As she walks along beside me, chattering gayly, her hands are shoved into the little pockets of a tan jacket, which almost covers her clean white apron and red dress. Her bright ways complete the happiness of a sunny morning, and when I see her on a rainy one, they take the place of the sunshine and go with me all the day.

The above topics were based upon places or persons actually known to the writers. Now the class was requested to describe some object, place, or person existing only in the imagination, the 
description to contain color, action, and sound. The following description of "The Old Swimmin' Hole" came from a boy of sixteen. The paper shows that interest in subject leads to successful expression.

\section{THE OLD SWIMMIN' HOLE}

There is a place where the creek makes a bend and glides silently between two gently sloping banks, forming a deep, cool pool, made inviting by the dark shadows that lurk in its more sheltered nooks and the bright patches of sunlight that dance on the surface, as they come through the green leaves of the great trees that border the creek. As the passer-by approaches this retreat he hears a "whoop" unmistakably boyish, a second later a great splash, and he realizes instantly that he has invaded that sacred spot, known to every healthy boy glorying in the freedom of out-of-door life as "The Old Swimmin' Hole." As the observer looks closer he sees the spring-board still vibrating from the effects of its recent usage. On the grass lie various articles of wearing apparel dropped here and there by their owners as they hurried into the water. Going a little nearer, so as to look over the bank, he sees the "fishes" dashing water into each other's faces, trying to see who can swim the fastest, trying to see who can dive the farthest, and attempting all of the innumerable feats that only boys know of. In contrast to the shrill yells and whistles of the boys, he hears the songs of the birds, hopping from branch to branch, wondering at the strange medley below them. The sky above all is deep blue, with an occasional fleecy white cloud floating slowly across it. As the sun gradually creeps lower and lower, and the shadows on the water grow longer and longer, the boys, one by one, begin to think that it must be about four o'clock; so they reluctantly retrace their steps homeward, hoping that those at home won't notice their wet hair and unusually clean faces, and by these evidences know they have "skipped school."

Description of scenes represented in pictures is generally considered elementary work. It can well be made of use in the secondary school if there is a clearly defined aim - the aim of bringing out the central idea of the picture, or the motive directing the artist. This is accomplished in the following, written by a boy in the third year of the high school:

\section{SAVED}

On the south side of the study hall during the recent art exhibit there hung a large picture entitled "Saved." It was a picture of three dogs and a kitten at the bottom of a short flight of stone steps.

The largest dog of the three, a fine specimen of the Newfoundland breed, is lying on the ground in an easy position with his head erect. Between his outstretched paws a small kitten has taken refuge and has defiantly raised her ruffled tail. Her confident air, as exhibited under the protection of her large 
friend, seems rather humorous when one tries to picture the kitten under similar conditions, but without similar protection.

The Newfoundland makes an appropriate background for the confident little creature. His eyes are half closed, as though nothing of importance were happening, but the expression about his mouth suggests the presence of a deep, low growl, which is a warning to the two active miscreants in the foreground.

The kitten's two enemies are at a safe distance from their shaggy relative, and are evidently in a perplexed state of mind as to their next move; they are, however, in such a position that they can either turn tail and run, or spring at the kitten, on very short notice. The little fox terrier, especially, is a perfect type of condensed activity. Every nerve in his graceful little body is alert for an opportunity to pounce on the little kitten, should she decide to seek safety in some other quarter. But the way his intelligent little head is cocked on one side, and the desperate attempt with which he tries to get a respectable wag from his stubby little tail, show that he has great respect for the shaggy Newfoundland that is guarding the coveted object of his innate hatred. His mate, a black, curly terrier, is a little farther off and evidently intends to allow the fox terrier the laying of all the besieging plans.

The picture as a whole aptly illustrates that instinct in the weak, so common even among the very lowest animals, to seek protection from the stronger. The little kitten's every attitude illustrates this, and every detail in the picture carries out this thought.

With the object of giving the class practice in thinking along a double line of thought, of making a comparison, and practice in the use of such contrasting conjunctions and phrases as properly connect the successive parts of such a composition, an assignment was made requiring the pupils to describe two objects in such a way as to make a comparison. A paper written, entitled "My Choice," was full of life and interest.

\section{MY CHOICE}

On my way home from down-town I had seen two of the loveliest gowns. It was a joy to look at them, but alas for my peace of mind after that look! Even when I reached home I kept seeing them, and the more I thought about them, the more I knew I needed a new gown. By ten o'clock that night I had decided one or the other of these dresses would be mine the next morning. I couldn't afford to get them both. Which one would it be? Everything must be considered in determining this most momentous question.

After I had gone to bed I could see them both just as they had hung in the shop window. One was a pale gray, just a color I knew would blend beautifully with every ribbon, belt, and collar I had. The goods was of a soft, "crêpy" nature, very fine and thin. The gown itself, although plainly made, was so 
constructed that it could be worn on "dress occasions" or just for "ordinary." It was long, $\mathrm{Oh}$ ! beautifully long and full, with just enough sweep to hang gracefully when one walked.

Then the other. Was there ever a dearer, daintier little frock? It was long, too, but it didn't sweep along so grandly as did the other. The color of this one was pink. I believe you would call it pink, although when you looked at it in another light it looked opalescent, white in one place, just a tiny bit green in another, and in still other parts slightly blue. The goods, thin, but smooth and close, looked like the inside of a bit of mother-of-pearl. Still, it was cut low and had short sleeves, and economy must be considered. I knew it never could be made over nor worn again when that style "went out."

The next morning, after dreaming of dresses, and dresses, and dresses, I went down-town, shutting my eyes tight as I passed the shop window, went in and told the salesman to send down that gray gown in the window and-please give me the bill. I never looked at the pink one. I didn't dare to, you know, because I was sure I could get so much more "wear" out of the other.

Paragraph structure can best be taught by giving an opening sentence, with directions to complete the paragraph thus begun by using illustration, or repetition, or contrast, or particular statement in place of the general statement given. The following paragraph was developed by illustration of the abstract idea contained in the given first sentence:

Liberty for any person is true liberty only when it does not infringe on the rights of other persons. Jeremiah Jenkins did not believe this. He thought that because he disliked dogs his neighbor had no right to own one. So one day when Jenkins found the dog racing across a newly plowed field in pursuit of a rabbit, he believed it was his right to kill the animal. He had his gun, and in a few seconds the dog lay motionless upon the freshly turned furrows. $\mathrm{Mr}$. Jones, Jeremiah's neighbor, thoroughly believed the statement made at the beginning of this paragraph. He called upon Jeremiah. Many unkind words were said. Jeremiah declared that he had a right to kill the dog because he lived in a country where everyone was at liberty to do as he pleased. The case was taken into court and was decided against Jeremiah, who discovered, too late, that his liberty extended only to the point where that of someone else began.

A call for a paragraph stating what the writer most admired in a boy, brought the following:

I might choose as the title of this paragraph honesty, or bravery, or boldness, or dignity, or firmness, or hardihood; but any one of these terms would not express what I most admire in a boy. A boy may be brave in one sense of the word, but not honest; bold, but not dignified; firm, but not hardy. Here is a boy who is brave. By brave I do not mean that he is always ready to start a quarrel; 
I do not mean, necessarily, that he will shoulder his musket and go to war, although that is bravery; but I do mean that he will stand up for the right wherever he may be. There is a boy who is bold, not taking the word as meaning too forward, but as meaning courageous. This boy is dignified-not haughty, but honorable. Another one is firm, having the strength of character to resist temptation. Still another is hardy-not necessarily having a strong constitution, but being intrepid in the face of difficulties. But here is a boy who possesses all these virtues; one who possesses manliness, and who, therefore, is a manly boy. As this boy grows up and passes through life, people will say of him: "He is a man;" and, when he dies and is buried, the inscription on his tombstone will be: "Here lies a man."

Work in exposition will easily follow such practice in paragraphwriting. Compositions written to explain some abstract idea or to define some term may be full of vigor and interest if the pupils have been trained in definite means by which to attain a definite endclearness and life. From the direction to explain clearly what the pupil meant by a successfully built house, a successful story, a successful stenographer, a successfully managed firm, etc., papers containing original thought were obtained. One, written by a boy, is submitted below:

\section{A SUCCESSFUL HOUSEWIFE}

The successful housewife of today must first of all be capable of economy; that is, capable of the management of the household matters, especially as to their expense. She must know how to avoid waste and how to apply her money to the best advantage. By an economical woman I do not mean one who is parsimonious-far from it-but she should be saving both in the decoration of her home and in the kitchen. The housekeeper who can cook up yesterday's chicken bones into a delicate soup is the one for whom success is waiting. By economy in the decoration of the home I mean a selection of things which will not only be inexpensive, but which will be in harmony with each other, making the house pleasant and attractive as well as comfortable and homelike.

Hand in hand with economy in decoration comes originality. The wife and mother who is original can, in her decoration, make the home pleasant and happy for the tired husband as he returns from his work at eventide, as well as a source of interest and amusement for the son, who, if it were not for the little den with the good pictures, many trinkets, and collection of well-selected books, might be away at the club, on the street, or perhaps in even worse places.

Every successful housewife will have some system, which she will follow closely, in order that she may find time for recreation, for clubs, and for social affairs, all of which serve to make the home happier and brighter. 
The mistress of the house must, also, be hospitable, to insure for her true success. She must be able to entertain in an easy manner, to make her friends always welcome and at home, as well as to be easily entertained herself.

Pupils should by all means be allowed at times to write on selfselected topics; for by looking for topics in the doings of the world at large, in their reading, and especially in the daily routine of life, they will learn to see the literary possibilities in ordinary things, and their writing will grow more full of life as it is the outgrowth of lifelike interests.

That is what we must seek in the composition work of the highschool pupils-life, and a vital interest on the pupil's part in the thing to be said and in the way to say it. A definite literary problem to be successfully solved by the pupil will produce this result. 